\title{
Biometan jako paliwo transportowe. Warunki użytkowania pojazdów i wymagania jakościowe paliwa
}

\begin{abstract}
Przedmiotem artykułu jest omówienie kluczowych zagadnień związanych z użytkowaniem biometanu w transporcie. Określono wymagania techniczne pojazdów z napędem gazowym, dokonano analizy wymagań jakościowych biometanu do zasilania silników pojazdów samochodowych oraz przedstawiono dokumenty prawne i normatywne dotyczące stosowania biometanu do napędu pojazdów.
\end{abstract}

Słowa kluczowe: uzdatnianie biogazu, biometan, sprężony gaz ziemny, CNG, pojazdy napędzane gazem ziemnym.

\section{Biomethane as a transport fuel. Technical conditions for use of vehicles and fuel quality requirements}

The subject of the article is to discuss key issues related to the use of biomethane in transport. Technical requirements for gas-powered vehicles are determined, an analysis of quality requirements of biomethane as automotive fuel was performed and the legal and normative documents on the use of biomethane for vehicles are presented.

Key words: biogas upgrading, biomethane, compressed natural gas, $\mathrm{CNG}$, natural gas vehicles.

\section{Wprowadzenie}

Stosowanie biogazu do celów transportowych jest jednym z najwyżej ocenianych kierunków promocji odnawialnych źródeł energii związanych z produkcją zielonej energii. Dyrektywa 2009/28/WE [11] wskazuje na wykorzystanie biogazu jako biopaliwa o jednym z najwyższych wskaźników redukcji emisji gazów cieplarnianych oraz przyczyniającego się do poprawy stanu środowiska naturalnego. Stosowanie biometanu w silnikach pojazdów jest źródłem mniejszej emisji szkodliwych dla zdrowia i środowiska substancji i zanieczyszczeń niż w przypadku benzyny czy oleju napędowego, co jest realizacją celów zawartych w Dyrektywie Parlamentu Europejskiego i Rady 2009/33/WE z dnia 23 kwietnia 2009 r. w sprawie promowania ekologicznie czystych $i$ energooszczędnych pojazdów transportu drogowego. Ponadto biometan jest paliwem charakteryzującym się wysokim bezpieczeństwem użytkowania i zapewniającym bardzo dobre parametry eksploatacyjne, m.in. z uwagi na wysoką liczbę oktanową.

Pomimo iż techniczne i logistyczne uwarunkowania produkcji i wykorzystania biometanu są zasadniczo znane i wdrażane, brakuje powszechnych i jasnych kryteriów dotyczących jakości biometanu, zarówno wprowadzanego do sieci gazowej, jak i użytkowanego jako paliwo w silnikach pojazdów mechanicznych. Brak również zaleceń co do optymalizacji technologii wytwarzania biometanu stosowanego jako paliwo transportowe.

\section{Warunki użytkowania pojazdów napędzanych biometanem}

Biometan jako paliwo transportowe używany jest w pojazdach przystosowanych do spalania gazu ziemnego bądź jako paliwo zamienne dla sprężonego gazu ziemnego (CNG) bądź też jako składnik mieszanki z gazem ziemnym. Biometan można wykorzystywać przede wszystkim w komunikacji miejskiej, pojazdach transportu komunalnego i dystrybucji 
lokalnej. Traktowanie biometanu jako czynnika uzupełniającego CNG jest najbardziej uzasadnione, umożliwia bowiem wykorzystanie go w największej liczbie pojazdów. Wymaga to opracowania norm jakościowych dla biometanu, które zapewnią właściwą eksploatację pojazdów napędzanych sprężonym gazem ziemnym.

Ze względu na zmienność składu gazu ziemnego dystrybuowanego przez różnych operatorów sieci gazowych, konstrukcja silników samochodów z napędem CNG powinna zapewniać ich prawidłową pracę, uwzględniając pewną elastyczność co do składu paliwa, jeśli samochody te mają być sprzedawane w różnych krajach. $Z$ tej przyczyny, przy zachowaniu standardów jakości dla gazu ziemnego, możliwe jest zasilanie tych samych silników biometanem. W związku z powyższym można traktować wymagania odnośnie warunków technicznych i bezpieczeństwa użytkowania dla pojazdów z silnikami zasilanymi biometanem jako tożsame z oczekiwaniami dla pojazdów napędzanych CNG.

W Polsce wymagania techniczne dla pojazdów napędzanych sprężonym gazem ziemnym (CNG) zawarte są w Rozporzadzeniu Ministra Infrastruktury z dnia 4 maja 2011 r. zmieniającym rozporządzenie $w$ sprawie warunków technicznych pojazdów oraz zakresu ich niezbędnego wyposażenia (Dz. U. z 2011 r. nr 104, poz. 607) [20]. Elementy i zespoły instalacji powinny być homologowane według obowiązującej wersji Regulaminów EKG ONZ dotyczących instalacji zasilania gazem [16].

Bezpieczeństwo użytkowania metanu jako paliwa transportowego ocenia się wyżej niż benzyny, oleju napędowego czy LPG. Temperatura zapłonu metanu wynosi ponad $630^{\circ} \mathrm{C}$ i jest wyraźnie wyższa niż np. benzyny, co utrudnia samozapłon. Granice palności mieszczą się w wąskim przedziale procentowego udziału gazu ziemnego w powietrzu, co w połączeniu z dużą lotnością sprawia, że - w przeciwieństwie do pojazdów z napędem LPG - dopuszcza się ich parkowanie na parkingach podziemnych, pod warunkiem zapewnienia dobrej wentylacji pomieszczenia [19].

Technologia wytwarzania zbiorników wysokociśnieniowych gwarantuje bezpieczeństwo ich użytkowania nawet pod ciśnieniem znacznie przewyższającym ciśnienie robocze, które osiąga wartość od 20 do $25 \mathrm{MPa}$ w czasie tankowania. Nawet w przypadku rozszczelnienia zbiornika ze sprężonym gazem ziemnym następuje wyciek gazu bez wybuchu i rozerwania butli. W czasie wycieku gazu dochodzi do gwałtownego obniżenia jego temperatury wskutek rozprężenia, co ze względu na wysoką temperaturę zapłonu uniemożliwia zapalenie się gazu. Dlatego też celowo wykorzystuje się pojazdy z napędem CNG w warunkach, gdy może dojść do ekstremalnych sytuacji (np. jako radiowozy policyjne, karetki, pojazdy obsługi portów lotniczych).
Dla zapewnienia odpowiedniej wytrzymałości, ze względu na wysokie ciśnienia, konieczne jest specjalistyczne wykonanie zbiorników paliwa CNG. Są one butlami w kształcie walca, ze stali lub kompozytu [6]. Zbiorniki kompozytowe, ważące około 1/3 tego co metalowe, są ponad dwukrotnie droższe. W samochodach osobowych z silnikami przystosowanymi fabrycznie do spalania gazu zbiorniki montowane są w przestrzeni podpodłogowej pojazdu. W autobusach, zwłaszcza niskopodłogowych, częstym rozwiązaniem jest montaż butli na dachu. Jest to sposób korzystny ze względów bezpieczeństwa, ponieważ metan jako lżejszy od powietrza w razie rozszczelnienia ulatnia się do góry. Butle połączone są przewodem zbiorczym, a każda z nich wyposażona jest w zawór odcinający i zawór bezpieczeństwa. Zainstalowanie centralnego zaworu odcinającego umożliwia całkowite przerwanie dopływu gazu do silnika [2].

Zasady bezpieczeństwa użytkowania pojazdów napędzanych sprężonym gazem ziemnym ujęte są w normie PN-EN 13423:2002 [14], zawierającej wskazania i wytyczne dotyczące użytkowania pojazdów zasilanych gazem ziemnym dla użytkowników pojazdów, salonów sprzedaży, operatorów parkingów, stacji tankowania i obsługi. Jako najważniejsze zalecenia można wymienić obowiązek wyposażenia w wentylację obszarów zamkniętych przeznaczonych do parkowania pojazdów z napędem CNG i wykonywania prac przy układzie zasilania przez osobę kompetentną, czyli przeszkoloną, posiadającą odpowiednią wiedzę i doświadczenie. W przypadku podejrzenia wycieku gazu zalecane jest również zabezpieczenie przed źródłami zapłonu (odległość $3 \mathrm{~m}$ ) do czasu odizolowania zbiorników gazu. Po każdej pracy przy elementach zawierających gaz należy sprawdzić układ zasilania gazem pod względem przecieków, z zastosowaniem odpowiednich metod wykrywania ulotów gazu. Ponadto zalecane jest sprawdzenie i przebadanie zbiornika gazowego, który mógł ulec uszkodzeniu podczas kolizji drogowej, przez organ Dozoru Technicznego.

Pojazdy napędzane sprężonym gazem powinny ponadto być użytkowane zgodnie z wymaganiami zawartymi w Rozporządzeniu Rady Ministrów w sprawie rodzajów urządzeń technicznych podlegających dozorowi technicznemu z dnia 7 grudnia 2012 r. (Dz.U. nr 0, poz. 1468) [22] ze względu na to, że dozorowi technicznemu podlega ciśnieniowy zbiornik na gaz sprężony, służący do zasilania silników spalinowych w pojazdach. Bezpieczeństwo tankowania biometanu określają takie same przepisy jak dotyczące gazu ziemnego. Wytyczne bezpieczeństwa na stacjach CNG, zgodne ze standardem technicznym ST-IGG 1601:2012 [24], mają zastosowanie również przy tankowaniu biometanu. Poszczególne podzespoły i przewody stacji powinny być wyposażone w urządzenia zabezpieczające przed przekroczeniem 
dopuszczalnego ciśnienia roboczego. Zgodnie z wymaganiami Regulaminu nr 110 Europejskiej Komisji Gospodarczej ONZ (EKG/ONZ), najwyższe dopuszczalne ciśnienie na złączu tankowania może wynosić $26 \mathrm{MPa}$ [5]. Aby zapewnić ochronę przed pożarem i wybuchem, konstrukcja stacji tankowania oraz poszczególne urządzenia, w które jest wyposażona, powinny spełniać wytyczne Rozporzadzenia Ministra Gospodarki z dnia 22 grudnia 2005 r. w sprawie zasadniczych wymagań dla urzadzeń $i$ systemów ochronnych przeznaczonych do użytku w systemach zagrożonych wybuchem (Dz. U. z 2005 r. nr 263, poz. 2203) [17] oraz Rozporzadzenia Ministra Spraw Wewnętrznych i Administracji $z$ dnia 7 czerwca 2010 r. w sprawie ochrony przeciwpożarowej budynków, innych obiektów budowlanych i terenów (Dz. U. z 2010 r. nr 109, poz. 719) [21], a także ISO/DIS 16923.2: Natural gas fuelling stations - CNG stations for fuelling vehicles (Stacje tankowania dla pojazdów zasilanych gazem ziemnym).

\section{Analiza wymagań jakościowych biometanu jako paliwa transportowego}

W porównaniu z biometanem gaz ziemny ma szerszy zakres zmienności składu. Obecność wyższych węglowodorów w gazie ziemnym przyczynia się do zwiększenia podatności na spalanie detonacyjne $\mathrm{w}$ silnikach, mierzonej liczbą metanową (MN), gdzie czysty metan posiada MN 100, a czysty wodór MN 0 . Gaz ziemny z małą zawartością węglowodorów ciężkich i biometan mają MN około 100, a obecność wyższych węglowodorów w gazie ziemnym zmniejsza MN do poziomu nawet poniżej 70. Zawartość gazów inertnych $\left(\mathrm{CO}_{2} \mathrm{i} \mathrm{N}{ }_{2}\right)$ zwiększa wartość liczby metanowej powyżej 100 .

Jedyną normą, która specyfikuje wymagania dla biometanu stosowanego jako paliwo transportowe, jest szwedzka norma SS 155438:1999 [23]. Wytyczne w niej zawarte przedstawiono w tablicy 1.

Wartości dla biometanu typu A dotyczą paliwa do silników bez regulacji współczynnika składu mieszanki lambda (tzw. ubogiego spalania), stosowanych w pojazdach ciężkich, takich jak samochody ciężarowe i autobusy. Wartości dla biometanu typu B obejmują paliwo do silników z regulacją składu mieszanki, stosowane przy spalaniu stechiometrycznym, np. samochodów osobowych. Obecnie większość pojazdów ciężkich również posiada regulację składu mieszanki lambda.

W innych krajach, poza Szwecją, przyjmuje się wymagania jakościowe dla biometanu tożsame $\mathrm{z}$ tymi dla CNG. Jakość gazu ziemnego, stosowanego jako paliwo do pojazdów, jest standaryzowana w normie międzynarodowej ISO CD 15403, w Polsce wdrożonej jako PN-EN ISO 15403-1:2010 i PKN ISO/TR 15403-2:2010. Wytyczne dotyczące jakości gazu zawarte są w części drugiej: PKN ISO/TR 15403-2:2010 Gaz ziemny. Gaz stosowany jako sprężone paliwo do pojazdów. Część 2: Specyfikacja dotyczaca jakości [13]. Norma odnosi się jedynie do sprężonego gazu ziemnego wprowadzanego do zbiorników paliwa w pojazdach i nie dotyczy gazu doprowadzanego do stacji tankowania. Za wszelkie zmiany składu gazu ziemnego dostarczanego do stacji tankowania, mające na celu spełnienie tych wymagań, odpowiedzialność ponosi operator stacji tankowania paliwa dla pojazdów. Za istotne cechy jakościowe gazu uznaje się zawartość wody, związków siarki, cząstek stałych, węglowodorów wyższych, $\mathrm{CO}_{2}$, tlenu w postaci wolnej, glikolu/metanolu, zawartość oleju, składników po-

Tablica 1. Wymagania normy SS 155438:1999 dla stosowania biometanu jako paliwa do silników pojazdów

\begin{tabular}{|c|c|c|c|}
\hline Parametr & Jednostka & $\begin{array}{l}\text { Biometan } \\
\text { typ A }\end{array}$ & $\begin{array}{l}\text { Biometan } \\
\text { typ B }\end{array}$ \\
\hline Liczba Wobbego & $\mathrm{MJ} / \mathrm{m}^{3}$ & $44,7 \div 46,4$ & $43,9 \div 47,3$ \\
\hline Zawartość metanu & $\%$ obj. ${ }^{*}$ & $97 \pm 1$ & $97 \pm 2$ \\
\hline Punkt rosy pod największym ciśnieniem magazynowania & ${ }^{\circ} \mathrm{C}$ & $\mathrm{T}-5^{* *}$ & $\mathrm{~T}-5 * *$ \\
\hline Zawartość wody, maksimum & $\mathrm{mg} / \mathrm{m}^{3}$ & 32 & 32 \\
\hline $\mathrm{CO}_{2}+\mathrm{O}_{2}+\mathrm{N}_{2}$, maksimum & $\%$ obj. & 4,0 & 5,0 \\
\hline $\mathrm{O}_{2}$, maksimum & $\%$ obj. & 1,0 & 1,0 \\
\hline Zawartość siarki całkowitej & $\mathrm{mg} / \mathrm{m}^{3}$ & 23 & 23 \\
\hline $\begin{array}{l}\text { Zawartość związków azotu, poza } \mathrm{N}_{2} \text {, przeliczonych na amoniak, } \\
\text { maksimum }\end{array}$ & $\mathrm{mg} / \mathrm{m}^{3}$ & 20 & 20 \\
\hline Maksymalny wymiar cząstek stałych & $\mu \mathrm{m}$ & 1 & 1 \\
\hline
\end{tabular}

* Warunki odniesienia: temp. 273,15 K i ciśnienie 101,325 kPa

** T - najniższa średnia dzienna temperatura w skali miesiąca. 
wodujących korozję. W normie, jako wartość graniczną zawartości związków siarki podano $120 \mathrm{mg} / \mathrm{m}^{3}$, dla poszczególnych związków siarki określono dopuszczalną zawartość $\mathrm{H}_{2} \mathrm{~S} \leq 5 \mathrm{mg} / \mathrm{m}^{3}$, a merkaptanów $\leq 15 \mathrm{mg} / \mathrm{m}^{3}$. W celu uniknięcia wprowadzenia do układu zasilania silnika cząstek stałych, zalecono zastosowanie filtrów o następujących wymiarach: łączniki do tankowania: $40 \mu \mathrm{m}$, systemy iniekcyjne/regulatory: $5 \mu \mathrm{m}$, inżektory: $1 \mu \mathrm{m}$. Określono dopuszczalną zawartość graniczną $\mathrm{CO}_{2}$ na poziomie $3 \%$ obj., taką samą dopuszczalną wartość graniczną ustalono dla tlenu niezwiązanego. Za szkodliwą dla elementów silnika uznano obecność glikolu/metanolu. Zwrócono uwagę, że zbyt duża zawartość oleju, istotna dla smarowania układu paliwowego, jest szkodliwa, ponieważ może zatykać jego części. Powyższa norma została oparta na standardzie amerykańskim SAE J1616 z 1994 r.

Zdecydowanie bardziej restrykcyjne zalecenia zawiera norma niemiecka DIN 51624:2008-02 [10], której wymagania odnośnie zawartości siarki całkowitej (zalecany jest gaz „pozbawiony siarki” (schwefelfrei) - co oznacza dopuszczalną zawartość siarki całkowitej $8 \mathrm{mg} / \mathrm{m}^{3}$, łącznie z nawaniaczem) i metanu (minimalna liczba metanowa wynosząca 70) wykluczają stosowanie jako paliwa silnikowego gazu rozprowadzanego siecią w wielu krajach europejskich.

W Polsce wymagania dla gazu ziemnego do napędu pojazdów reguluje Rozporządzenie Ministra Gospodarki z dnia 28 grudnia 2006 r. w sprawie wymagań jakościowych dla sprężonego gazu ziemnego (CNG) (Dz. U. z 2006 r. $\mathrm{nr} 251$, poz. 1850) [18]. Najistotniejsze wymagania jakościowe dla wysokometanowego gazu (grupy E) CNG podano w tablicy 2.
Ze względu na możliwość tankowania gazu sieciowego w krajach, w których istnieją lokalne sieci biometanu lub jest on wtłaczany do systemu gazu ziemnego, istotne jest dokonanie analizy parametrów dla biometanu wprowadzanego do sieci. Zestawienie wymagań w tym zakresie przedstawiono w tablicy 3 [7].

Zminimalizowanie zawartości zanieczyszczeń do podanych w tabelach wartości granicznych ma istotne znaczenie ze względu na ich niekorzystny wpływ na przebieg procesu spalania w silnikach samochodowych.

Zanieczyszczeniem, któremu poświęcono wiele uwagi w dotychczas opracowanych normach, jest siarka. Zakres zmienności zawartości związków siarki w biogazie, przede wszystkim w postaci siarkowodoru, jest bardzo duży - od $\mathrm{kilku} \mathrm{mg} / \mathrm{m}^{3}$ do kilku $\mathrm{g} / \mathrm{m}^{3}$. Obecna w biogazie para wodna tworzy z siarkowodorem związki o charakterze korozyjnym, przyśpieszając zniszczenie elementów silnika. Ze względu na układ katalitycznego oczyszczania spalin producenci samochodów dopuszczają bardzo niski poziom zawartości siarki w gazie zasilającym. W gazie ziemnym rozprowadzanym siecią źródłem siarki jest przede wszystkim dodawany dla bezpieczeństwa użytkowania środek nawaniający. W normie europejskiej EN 16726 Gas infrastructure - Quality of gas Group $H$ określono dopuszczalne stężenie związków siarki na poziomie $20 \mathrm{mg} / \mathrm{m}^{3}$, bez obecności nawaniacza, którego stężenie powinny regulować normy krajowe.

Obecność siloksanów dotyczy przede wszystkim gazów ze składowisk odpadów, ewentualnie fermentacji osadów ze ścieków komunalnych. Zawartość siloksanów w surowym biogazie wynosi zazwyczaj $10 \div 20 \mathrm{mg} / \mathrm{m}^{3}$, choć może sięgać

Tablica 2. Wymogi jakościowe dla wysokometanowego gazu CNG

\begin{tabular}{|c|c|c|c|}
\hline \multirow{2}{*}{ Właściwość } & \multirow{2}{*}{ Jednostki } & \multicolumn{2}{|c|}{ Zakresy } \\
\hline & & minimum & maksimum \\
\hline Zawartość siarkowodoru ${ }^{1}$ & $\mathrm{mg} / \mathrm{m}^{3}$ & - & 7 \\
\hline Zawartość siarki całkowitej $^{1}$ & $\mathrm{mg} / \mathrm{m}^{3}$ & - & 40 \\
\hline Zawartość par rtęci ${ }^{1}$ & $\mu \mathrm{g} / \mathrm{m}^{3}$ & - & 30 \\
\hline Ciepło spalania $^{1}$ & $\mathrm{MJ} / \mathrm{m}^{3}$ & $\begin{array}{l}34 \text { - dla nominalnej } \\
\text { liczby Wobbego } 50^{2}\end{array}$ & \\
\hline Zawartość wody & $\mathrm{mg} / \mathrm{m}^{3}$ & & $30^{3}$ \\
\hline \multicolumn{4}{|l|}{ Zawartość wyższych węglowodorów ${ }^{4}$} \\
\hline propan & \multirow{2}{*}{$\%$} & & 5,8 \\
\hline butan & & & 1,8 \\
\hline Zawartość pyłu o średnicy cząstek większej niż $5 \mu \mathrm{m}$ & $\mathrm{mg} / \mathrm{m}^{3}$ & & 1 \\
\hline Zawartość tlenu & $\%(\mathrm{~mol} / \mathrm{mol})$ & & 0,2 \\
\hline
\end{tabular}

${ }^{1}$ Warunki odniesienia dla objętości: temperatura: 273,15 K, ciśnienie 101,325 kPa.

${ }^{2}$ Dopuszczalny zakres zmienności wynosi: $45 \div 54$.

${ }^{3}$ Przy ciśnieniu $20 \mathrm{MPa}$ i temperaturze $-20^{\circ} \mathrm{C}$.

${ }^{4}$ Wartości określone dla temperatury $-30^{\circ} \mathrm{C}$. 
Tablica 3. Zestawienie parametrów dla biometanu rozprowadzanego siecią lub użytkowanego jako paliwo transportowe (wartości dla Szwecji)

\begin{tabular}{|c|c|c|c|c|c|c|c|c|c|}
\hline Parametr & Jednostka & Austria & Francja & Belgia & Czechy & Niemcy & Holandia & Szwecja & Szwajcaria \\
\hline $\mathrm{CH}_{4}$ & $\%$ obj. & $\geq 96$ & $\geq 86$ & $\geq 85$ & $\geq 95$ & & $\geq 80$ & $\geq 97$ & $\geq 96$ \\
\hline $\mathrm{CO}_{2}$ & $\%$ obj. & $\leq 3$ & $\leq 2,5$ & $\leq 2,5$ & $\leq 5$ & $\begin{array}{c}\leq 6 \\
\text { (suchy) }\end{array}$ & $\leq 6$ & $\leq 3$ & $\leq 6$ \\
\hline $\mathrm{O}_{2}$ & $\%$ obj. & $\leq 0,5$ & $\leq 0,01$ & & $\leq 0,5$ & $\begin{array}{c}\leq 0,5 \\
\text { (mokry) } \\
3 \text {, suchy }\end{array}$ & $\leq 0,5$ & $\leq 1$ & $\leq 0,5$ \\
\hline $\mathrm{H}_{2}$ & $\%$ obj. & $\leq 4$ & $\leq 6$ & $\leq 0,1$ & & $\leq 5$ & $\leq 12$ & $\leq 0,5$ & $\leq 4$ \\
\hline $\mathrm{CO}$ & $\%$ obj. & & $\leq 2$ & $\leq 0,2$ & & & $\leq 1$ & & \\
\hline $\begin{array}{l}\text { Siarka } \\
\text { całkowita }\end{array}$ & $\mathrm{mg} / \mathrm{m}^{3}$ & $\leq 10$ & $\leq 30$ & $\leq 30$ & $\leq 30$ & $\leq 30$ & $\leq 45$ & $\leq 23$ & $\leq 30$ \\
\hline Siarkowodór & $\mathrm{mg} / \mathrm{m}^{3}$ & $\leq 5$ & $\leq 5$ & $\leq 5$ & $\leq 7$ & $\leq 5$ & $\leq 5$ & $\leq 10$ & $\leq 5$ \\
\hline Merkaptany & $\mathrm{mg} / \mathrm{m}^{3}$ & $\leq 6$ & $\leq 6$ & $\leq 6$ & $\leq 5$ & $\leq 15$ & $\leq 10$ & & $\leq 5 \mathrm{ppm}$ \\
\hline $\begin{array}{l}\text { Chlorowco- } \\
\text { węglowodory }\end{array}$ & $\mathrm{mg} / \mathrm{m}^{3}$ & 0 & $\begin{array}{l}\leq 1(\mathrm{Cl}) \\
\leq 10(\mathrm{~F})\end{array}$ & $\begin{array}{l}\leq 1(\mathrm{Cl}) \\
\leq 10(\mathrm{~F})\end{array}$ & $\begin{array}{c}\leq 1,5 \\
(\mathrm{Cl}+\mathrm{F})\end{array}$ & 0 & $\begin{array}{c}\leq 50 / 25 \\
(\mathrm{Cl} / \mathrm{F})\end{array}$ & & $\leq 1$ \\
\hline Metale ciężkie & $\mathrm{mg} / \mathrm{m}^{3}$ & & $\begin{array}{c}\leq 1(\mu \mathrm{g} \\
\mathrm{Hg})\end{array}$ & $\leq 1(\mu \mathrm{g} \mathrm{Hg})$ & & $\leq 5$ & & & $\leq 5$ \\
\hline Siloksany & $\mathrm{mg} / \mathrm{m}^{3}$ & $\leq 10$ & & & $\leq 6(\mathrm{Si})$ & & $\begin{array}{c}\leq 5 \mathrm{ppm}= \\
6,2(\mathrm{Si})\end{array}$ & & \\
\hline Amoniak & $\mathrm{mg} / \mathrm{m}^{3}$ & $\begin{array}{l}\text { tech. } \\
\text { wolny }\end{array}$ & $\leq 3$ & $\leq 3$ & $\begin{array}{c}\text { nie } \\
\text { zawiera }\end{array}$ & & $\leq 3$ & $\leq 20$ & $\leq 20$ \\
\hline Woda & $\mathrm{mg} / \mathrm{m}^{3}$ & & & $\leq 110$ & & & & $\leq 32$ & \\
\hline Punkt rosy & ${ }^{\circ} \mathrm{C}$ & $\begin{array}{l}\leq-8 \\
40 \text { bar }\end{array}$ & $\begin{array}{l}\leq-5 \\
P_{\max }\end{array}$ & & $\leq-10$ & $\begin{array}{l}\text { temp. } \\
\text { gleby }\end{array}$ & $\begin{array}{c}\leq-10 \\
8 \text { bar }\end{array}$ & $\begin{array}{c}\leq t_{\min } \\
-5\end{array}$ & \\
\hline Nawaniacz & & $\begin{array}{c}\text { wymogi } \\
\text { sieci dystr. }\end{array}$ & $\begin{array}{c}15 \div 40 \mathrm{mg} \\
\mathrm{THT} / \mathrm{m}^{3}\end{array}$ & & & $\begin{array}{l}\text { wymogi } \\
\text { sieci dystr. }\end{array}$ & $\begin{array}{c}18 \div 40 \mathrm{mg} \\
\mathrm{THT} / \mathrm{m}^{3}\end{array}$ & $\begin{array}{l}\text { wymo- } \\
\text { gi sieci } \\
\text { dystr. }\end{array}$ & $\begin{array}{c}15 \div 25 \mathrm{mg} \\
\mathrm{THT} / \mathrm{m}^{3}\end{array}$ \\
\hline $\begin{array}{l}\text { Cząstki stałe, } \\
\text { maksymalna } \\
\text { średnica }\end{array}$ & & $\begin{array}{l}\text { tech. } \\
\text { wolny }\end{array}$ & $\begin{array}{l}\text { tech. } \\
\text { wolny }\end{array}$ & & $\begin{array}{c}\text { nie } \\
\text { zawiera }\end{array}$ & $\begin{array}{c}\text { nie } \\
\text { zawiera }\end{array}$ & $\begin{array}{l}\text { tech. } \\
\text { wolny }\end{array}$ & $\leq-1 \mu \mathrm{m}$ & \\
\hline
\end{tabular}

nawet $100 \mathrm{mg} / \mathrm{m}^{3}$. Przy spalaniu gazu zawierającego siloksany na głowicach cylindrów, tłokach i powierzchni przewodów powstaje osad krzemionki $\left(\mathrm{SiO}_{2}\right)$ lub krzemianów $\left(\mathrm{Si}_{\mathrm{x}} \mathrm{O}_{\mathrm{y}}\right)$. Powoduje to zanieczyszczenie i uszkodzenia czujników spalania lambda, ścieranie się powierzchni urządzeń, zatykanie się przewodów, redukcję mocy silnika, częstszą potrzebę wymiany oleju i inne problemy. Wśród wytwórców samochodów zdarzają się opinie, że nawet stężenie rzędu $0,1 \mathrm{mg} \mathrm{Si} / \mathrm{m}^{3}$ jest szkodliwe dla czujnika tlenu i może doprowadzić do konieczności jego wymiany w okresie eksploatacji samochodu [9]. W żadnej z norm nie ujęto tak niskiego poziomu dopuszczalnego siloksanów ze względu na brak normalizowanej metody badawczej w tym zakresie, jakkolwiek metodyka oznaczania siloksanów w biogazie została opracowana, m.in. w Instytucie Nafty i Gazu - PIB [8].

Obecność tlenu w biometanie sprzyja rozwojowi procesów korozyjnych. Głównym jego źródłem w biometanie jest powietrze wprowadzane w procesie usuwania siarkowodo- ru, zwłaszcza za pomocą metod biologicznych, w związku z czym zaleca się ograniczenie tych metod usuwania $\mathrm{H}_{2} \mathrm{~S}$. Kolejnymi składnikami tworzącymi w obecności wody związki o charakterze korozyjnym są amoniak i chlorowcowęglowodory, o znacznej szkodliwości dla zdrowia. W tym ostatnim przypadku prawdopodobieństwo ryzyka jest dość niewielkie, ponieważ chlorowcowęglowodory występują tylko w gazie ze składowisk odpadów i ich stężenie jest na ogół niskie.

Niejednolite graniczne wartości, zwłaszcza w zakresie zanieczyszczeń dla biometanu sieciowego, i brak wartości normatywnych dla biometanu stosowanego jako paliwo dla pojazdów były bodźcem do podjęcia prac normalizacyjnych w tym zakresie. Szczególnie istotne z punktu widzenia producentów samochodów było określenie wymagań jakościowych dla biometanu stosowanego jako paliwo do silników pojazdów.

Po zidentyfikowaniu problemu Komisja Europejska, poprzez wydanie Mandatu M/475, zleciła Europejskiemu 
Komitetowi Normalizacji (CEN) przygotowanie normy określającej wymagania dla biometanu, do zastosowania w transporcie i wtłaczania do sieci gazu ziemnego. W celu ułatwienia współpracy pomiędzy przemysłem gazowniczym a motoryzacyjnym został utworzony Komitet Techniczny CEN/TC 408, przejmujący część zakresu działań Komitetów Technicznych CEN/TC 19 Paliwa i CEN/TC 234 Infrastruktura Gazowa. Początkowo specyfikacja miała nie dotyczyć gazów innych niż biometan. W roku 2012 nastąpiła zmiana zakresu prac komitetów CEN/TC 408 i CEN/ TC 19. Nowy obszar działania CEN/TC 408 obejmuje stosowanie biometanu i gazu ziemnego jako paliw transportowych oraz wprowadzanie biometanu do sieci gazu ziemnego. Biometan i gaz ziemny jako paliwa transportowe zostały wyłączone z zakresu zainteresowania CEN/TC 19. Prace CEN/TC 408 zostały powiązane z działaniami Komitetu Technicznego ISO/PC 252, których rezultatem było przygotowanie normy ISO/DIS 16923 Natural gas fuelling stations - CNG stations for fuelling vehicles (Stacje tankowania dla pojazdów zasilanych gazem ziemnym).

Efekt prac prowadzonych od końca 2011 roku przez Komitet CEN/TC 408 stanowi wydany projekt normy, który obejmuje dwie części: prEN 16723-1 określającą specyfikację biometanu przeznaczonego do wtłaczania do sieci gazu ziemnego oraz prEN 16723-2 [15] definiującą wymagania dla biometanu stosowanego jako paliwo w transporcie. Specyfikacja zawarta w normie dotyczy zarówno biometanu pozyskiwanego w procesie fermentacji biomasy, jak i na drodze jej zgazowania.

Przedstawiono wymagania wartości granicznych dla gazu ziemnego i biometanu jako paliw pojazdów, oznaczanych za pomocą wymienionych metod testowych. Podane wartości są rekomendowane zarówno dla paliw o średniej liczbie metanowej określonej w EN 16726 na poziomie $\mathrm{MN}=65$, jak i dla paliw o wysokiej liczbie metanowej $\mathrm{MN}=80$. Ustalono dopuszczalne zawartości następujących składników:

- całkowitego krzemu lotnego na poziomie 0,1 lub $0,5 \mathrm{mg} \mathrm{Si} / \mathrm{m}^{3}$, stwierdzając, że wartości te uważane są za poziom bezpieczny i że należy prowadzić dalsze badania w celu ustalenia, czy akceptowalny jest wyższy poziom, - wodoru na poziomie $2 \% \mathrm{~mol} / \mathrm{mol}$,

- tlenu na poziomie $1 \% \mathrm{~mol} / \mathrm{mol}$,

- siarkowodoru i tlenosiarczku węgla na poziomie $5 \mathrm{mg} / \mathrm{m}^{3}$, jak w normie EN 16726.

Szczegółowe informacje co do działań zalecanych w zakresie minimalizacji szkodliwego wpływu zanieczyszczeń, potencjalnie zawartych w gazach będących przedmiotem normy, umieszczono w załącznikach o charakterze informacyjnym.

W załączniku A określono zagrożenia powodowane obecnością siloksanów w paliwie gazowym i możliwe źródła ich pochodzenia. Stwierdzono, że metoda analizy dla związków krzemu w gazie ziemnym nie została jeszcze w pełni zwalidowana, a podana wartość graniczna związków krzemu ma charakter wstępny. Mimo to określenie dopuszczalnej zawartości związków krzemu na bardzo niskim poziomie zostało uznane za ważny krok w kierunku ochrony pojazdów samochodowych przed spalaniem gazu zanieczyszczonego związkami krzemu. W odniesieniu do wodoru stwierdzono, że wyniki badań European Gas Research Group (GERG) [1] wykazują, iż możliwa jest domieszka maksymalnie 10\% objętości wodoru do gazu w niektórych częściach systemu gazu ziemnego. Jednak, według specyfikacji EKG ONZ R 110, wartość graniczna dla stalowych zbiorników w pojazdach na gaz ziemny została ustanowiona na poziomie $2 \%$ obj. Sugeruje się, że stężenie wodoru do $10 \%$ obj. mogłoby być dopuszczalne dla dedykowanych silników gazowych z zaawansowanym systemem kontroli, jeśli liczba metanowa dla mieszaniny wodoru i gazu ziemnego byłaby znacznie powyżej podanej minimalnej wartości, równej 65.

Kolejnymi potencjalnymi zanieczyszczeniami, których zawartość analizowano w Załączniku A normy prEN 16723-2, są olej sprężarkowy i cząstki stałe. Aby uniknąć problemów z olejem smarnym przeniesionym ze sprężarek stacji tankowania, pyłem i cząstkami stałymi, mogącymi powodować powstawanie osadów w postaci szlamów lub zablokowanie układu paliwowego pojazdu (na trasie połączenia silnika z urządzeniami, które mogą być źródłem oleju i cząstek stałych), zalecono instalowanie filtrów typu koalescencyjnego do usuwania oleju i cząstek stałych. Obecnie nie jest dostępna standaryzowana metoda do pomiaru zawartości oleju sprężarkowego. W celu oszacowania ilości oleju w gazie po sprężeniu i przejściu przez filtry zalecono monitoring zużycia oleju i jego odzysku w filtrach koalescencyjnych. Większość cząstek stałych powinna być wychwycona wraz z olejem. Dodatkowe ich usuwanie może się odbywać przy użyciu przeznaczonego do tego celu filtra cząstek stałych o nominalnej wielkości oczek mniejszej niż $5 \mu \mathrm{m}$, umieszczonego jak najbliżej dyszy napełniającej. Działanie filtra nie powinno być ograniczone przez krople wody, oleju lub węglowodorów ciekłych. Filtr ma za zadanie zatrzymać 99\% cząstek stałych o średnicy $\geq 5 \mu \mathrm{m}$ i 99\% cząstek ciekłych $\geq 10 \mu \mathrm{m}$.

Kolejne zalecenia zawarte w załączniku A dotyczą pomiaru punktu rosy wody i punktu rosy węglowodorów. Do ustalenia punktu rosy wody zaleca się metody pomiarowe określone w normach EN ISO 6327, ISO 10101-3 i obliczeniowe zawarte w normie EN ISO 18453. Punkt rosy węglowodorów mierzy się bezpośrednio (np. za pomocą przyrządów pomiarowych, zgodnie z ISO/TR 12148) lub oblicza się ze szczegółowego składu, zgodnie z wytycznymi zawartymi w normie ISO 23874 [12]. 
W załączniku B, również o charakterze informacyjnym, przedstawiono zalecenia dotyczące zawartości związków siarki w gazach będących przedmiotem normy.

W odniesieniu do zawartości siarki w gazie ziemnym decyzja Komitetu CEN/TC 408 w sprawie interpretowania różnych opinii na temat maksymalnej dopuszczalnej zawartości siarki stanowi, że:

- wartość normowana dla wtłaczania do sieci odpowiada specyfikacji zawartej w normie EN 16726, w której określono wartość dopuszczalną do $20 \mathrm{mg} / \mathrm{m}^{3}$ dla gazu nienawonionego i $30 \mathrm{mg} / \mathrm{m}^{3}$ dla gazu nawonionego,

- całkowita zawartość siarki przy zastosowaniu biometanu jako paliwa motoryzacyjnego nie powinna być większa niż $10 \mathrm{mg} / \mathrm{m}^{3}$, ze względu na możliwość zatrucia katalizatora spalin,

- biometan jako produkt uzdatniony zazwyczaj spełnia określone w specyfikacji paliw wymagania co do niskiej zawartości siarki $\left(10 \mathrm{mg} / \mathrm{m}^{3}\right)$, nie uwzględniając nawaniania.

\section{Podsumowanie}

Zastosowanie biometanu w transporcie jest uzasadnione, zarówno z uwagi na szerokie wykorzystanie odnawialnych źródeł energii, jak i zalety tego paliwa - niskoemisyjnego, bezpiecznego, pozwalającego zagospodarować biogaz o dużym wpływie na efekt cieplarniany. Powodzenie wykorzystania biometanu w transporcie opiera się na traktowaniu go jako paliwa wymiennego i uzupełniającego, a nie konkurencyjnego wobec CNG. Pozwala to na wykorzystanie samochodów przystosowanych do napędzania $\mathrm{CNG}$, jak i infrastruktury napełniania gazem, również do zasilania silników pojazdów samochodowych sprężonym biometanem. W związku z powyższym wymagania techniczne i warunki bezpieczeństwa użytkowania pojazdów napędzanych biometanem są tożsame $\mathrm{z}$ warunkami dla pojazdów z napędem $\mathrm{CNG}$.

Ze względu na rozbieżności występujące w aktach prawnych i normach dotyczących jakości biometanu dla zastosowań w transporcie i wtłaczania do sieci gazu ziemnego oraz oczekiwania zarówno przemysłu gazowniczego, jak i motoryzacyjnego, podjęto prace nad przygotowaniem normy w tym zakresie, składającej się z dwóch części, standaryzujących wymagania dla każdego z zastosowań. Projekt normy pr EN 16723-2 dotyczący zastosowania biometanu jako paliwa motoryzacyjnego, przygotowywany przez Komitet
Techniczny CEN TC/408, przewiduje bardzo niskie wartości dopuszczalne związków krzemu, których osiągnięcie może być trudne ze względu na brak znormalizowanych metod oznaczania w tym zakresie. Przedmiotem rozbieżności między oczekiwaniami przemysłu motoryzacyjnego a wymaganiami przemysłu gazowniczego jest dopuszczalna zawartość siarki całkowitej w gazie przeznaczonym do napędu pojazdów.

Biorąc pod uwagę oczekiwania przemysłu motoryzacyjnego w zakresie wymagań jakościowych biometanu przeznaczonego do napędu pojazdów, należy stwierdzić, że dobór efektywnej i atrakcyjnej ekonomicznie metody oczyszczania biogazu ze związków wpływających toksycznie na środowisko i niszcząco na stan zasilanych silników (połączonej z uzdatnianiem do parametrów gazu wysokometanowego, w zależności od parametrów biogazu), jest kluczowym elementem warunkującym powodzenie działań zmierzających w kierunku wprowadzenia biometanu na rynek paliw transportowych. O ile można spodziewać się, że szeroko stosowane $\mathrm{w}$ procesie wytwarzania biometanu metody usuwania dwutlenku węgla $[3,4]$ zapewnią uzyskanie paliwa o wymaganej liczbie metanowej, o tyle wyzwaniem będzie spełnienie wymagań dotyczących zawartości siarki całkowitej.

Prosimy cytować jako: Nafta-Gaz 2016, nr 4, s. 271-278, DOI: 10.18668/NG.2016.04.06

Artykuł nadesłano do Redakcji 16.11.2015 r. Zatwierdzono do druku 27.01.2016 r.

Artykuł powstał na podstawie pracy statutowej pt. Optymalizacja metod uzdatniania biogazu w celu uzyskania biometanu do zastosowania $w$ transporcie - praca INiG - PIB na zlecenie MNiSW; nr archiwalny: DK-4100-55/15, nr zlecenia: 55/WO/15.

\section{Literatura}

[1] Altfeld K., Pinchbeck D.: Admissible hydrogen concentrations in natural gas systems. Gas for Energy 2013, nr 3, s. 36-47 (GERG study).

[2] Gontarz A.: Stosowanie napędów hybrydowych spalinowoelektrycznych oraz gazowych paliw alternatywnych $w$ samochodach $i$ zwiazane z tym niebezpieczeństwa dla uzytkowników i prowadzacych działania ratowniczo-gaśnicze; http:// yadda.icm.edu.pl (dostęp: wrzesień 2015).

[3] Niemczewska J.: Characteristics of utilization of biogas technology. Nafta-Gaz 2012, nr 5, s. 293-297.
[4] Piskowska-Wasiak J.: Uzdatnianie biogazu do parametrów gazu wysokometanowego. Nafta-Gaz 2014, nr 2, s. 94-105.

[5] Sas J., Janik P.: Wybrane elementy zapewnienia bezpieczeństwa na stacjach tankowania CNG. BiTP 2014, vol. 33, issue 1, s. 83-91.

[6] Svensson M.: Challenges and Possibilities Biomethane powered transport. Energiforsk AB February, March 2015; http:// conference.sgc.se/ckfinder/userfiles/ files/4Biometane powered_transport.pdf (dostęp: wrzesień 2015).

[7] Svensson M.: European workshop Biomethane. Brussels 11 
March 2014, Compilated public information available in Marcogaz report (2006) „Injection of Gases from Non-Conventional Sources into Gas Networks"; http://european-biogas. eu/wp-content/uploads/2014/03/8/Mattias-Svensson_standards.pdf (dostęp: wrzesień 2015).

[8] Szlęk M., Król A.: Opracowanie metody analitycznej oznaczania siloksanów w biogazie. Nafta-Gaz 2013, nr 11, s. 851-857.

[9] Thrän D., Billig E., Persson T., Svensson M. i in: Biomethane. Status and Factors Affecting Market Development and Trade. A Joint Study by IEA Bioenergy Task 40 and Task 37, September 2014.

\section{Akty prawne i normatywne}

[10] DIN 51624:2008-02 Kraftstoffe für Kraftfahrzeuge - Erdgas - Anforderungen und Prüfverfahren.

[11] Dyrektywa Parlamentu Europejskiego i Rady 2009/28/WE $z$ dnia 23 kwietnia 2009 r. w sprawie promowania stosowania energii ze źródet odnawialnych zmieniajaca $i$ w następstwie uchylajaca dyrektywy 2001/77/WE oraz 2003/30/WE (Dz.U. E L 09.140.16).

[12] ISO 23874:2006 Natural gas - Gas chromatographic requirements for hydrocarbon dewpoint calculation.

[13] PKN-ISO/TR 15403-2:2010 Gaz ziemny. Gaz stosowany jako sprężone paliwo do pojazdów. Część 2: Specyfikacja dotyczqca jakości.

[14] PN EN 13423:2002 Użytkowanie pojazdów zasilanych sprężonym gazem ziemnym.

[15] prEN 16723-2 Natural gas and biomethane for use in transport and biomethane for injection in the natural gas networkPart 2: Automotive fuel specifications; www.gasnam.es/wpcontent/uploads/2015/03/CEN-TC408_N0293FprEN16723-2 (dostęp: wrzesień 2015).

[16] Regulamin nr 110 Europejskiej Komisji Gospodarczej Organizacji Narodów Zjednoczonych (EKG ONZ): Jednolite przepisy dotyczace homologacji: I. Określonych elementów pojazdów silnikowych wykorzystujacych w układach napędowych sprężony gaz ziemny CNG; II. Pojazdów w odniesieniu do montażu określonych homologowanych elementów stużacych do wykorzystania sprężonego gazu ziemnego
(CNG) w ich uktadach napędowych, Dz.U. E. Seria L Nr 72 z dnia 14 marca 2008, s. 113-226.

[17] Rozporządzenie Ministra Gospodarki z dnia 22 grudnia 2005 roku w sprawie zasadniczych wymagań dla urzadzeń $i$ systemów ochronnych przeznaczonych do użytku w systemach zagrożonych wybuchem (Dz.U. z 2005 r. nr 263, poz. 2203).

[18] Rozporzadzenie Ministra Gospodarki z dnia 28 grudnia 2006 roku $w$ sprawie wymagań jakościowych dla sprężonego gazu ziemnego (CNG) (Dz.U. z 2006 r. nr 251, poz. 1850).

[19] Rozporzadzenie Ministra Infrastruktury z dnia 12 kwietnia 2002 r. w sprawie warunków technicznych, jakim powinny odpowiadać budynki i ich usytuowanie (Dz.U. z 2015 r., poz. 1422).

[20] Rozporzadzenie Ministra Infrastruktury z dnia 4 maja 2011 r. zmieniajace rozporządzenie $w$ sprawie warunków technicznych pojazdów oraz zakresu ich niezbędnego wyposażenia $z$ dnia 31 grudnia 2002 r. w sprawie warunków technicznych pojazdów oraz zakresu ich niezbędnego wyposażenia (Dz.U. z 2011 r. nr 104, poz. 607).

[21] Rozporzadzenie Ministra Spraw Wewnętrznych i Administracji z dnia 7 czerwca 2010 r. w sprawie ochrony przeciwpożarowej budynków, innych obiektów budowlanych i terenów (Dz.U. z 2010 r. nr 109, poz. 719).

[22] Rozporządzenie Rady Ministrów z dnia 7 grudnia 2012 r. $w$ sprawie rodzajów urządzeń technicznych podlegajacych dozorowi technicznemu (Dz.U. z 2012 r. nr 0, poz. 1468).

[23] SS 155438:1999 Motor fuels - Biogas as fuel for high speed Otto engines.

[24] ST-IGG 1601:2012 Projektowanie, budowa i użytkowanie stacji CNG. Wymagania i zalecenia.

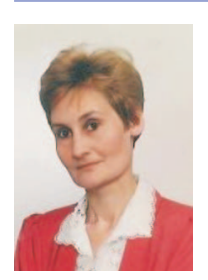

Mgr inż. Julita PISKOWSKA-WASIAK

Starszy specjalista badawczo-techniczny w Zakładzie Technologii Oczyszczania i Nawaniania Paliw. Instytut Nafty i Gazu - Państwowy Instytut Badawczy ul. Lubicz 25 A

31-503 Kraków

E-mail:piskowska@inig.pl 